МЕДИЦИНСКЕ СТРУКЕ ПРЕВЕНТИВНЕ МЕДИЦИНЕ НА

ПОДРУЧЈУ ТИМОЧКЕ КРАЈИНЕ - МЕДИЦИНСКА

БАКТЕРИОЛОГИЈА У ПЕРИОДУ ОД 1922. ДО 2013. ГОДИНЕ

Рајачка школа здравља

Петар Пауновић ${ }^{1}$, Слађана Ђорђевић ${ }^{2}$

\title{
MEDICAL PROFESSION IN THE AREA OF PREVENTIVE MEDICINE IN TIMOK REGION - MEDICAL BACTERIOLOGY IN THE PERIOD FROM 1922 TO 2013 Rajac School of Health
}

Petar Paunovic, Sladjana Djordjevic

\section{Сажетак}

Аутор у овоме раду пише о настајању, развоју и раду медииинске бактериологије, касније назване микробиологија и паразитологија, током претходне 94 године.

Аутор описује рад Сталне бактериолошке станице основане 1922. године у Зајечару, којом је руководио др Коста Тодоровић и у којој је радио чувени кијевски бактериолог проф. др Всеволд Љубински, а која је имала велики значај како за развој медицинске бактериологије на подручју Тимочке крајине тако и за развој других превентивних грана медицине, посебно епидемиологије и хигијене.

Највећи допринос медицинске бактериологије, која је између два светска рата функиионисала у Дому народног здравља у Зајечару, касније, после II светског рата, y Хигијенском, а данас у Заводу за јавно здравље „Тимок“ у Зајечару, био је у откривању заразних и паразитарних болести, посебно луеса и маларије, а затим и иревних заразних болести.

У овом раду аутор описује услове рада, опремљеност, садржај и методе бактериолошке, односно микробиолошке дијагностике и набраја лекаре који су у томе учествовали. Поред доприноса бактериолошкој, тј. микробиолошко-серолошкој $и$ паразитолошкој дијагностици, значајан је допринос развоју и серолошке и вирусолошке дијагностике код појединих болести и коришћењу антибиограма за лечене заразних болести.

\section{Summary}

In his work author writes about thebeginning, development and work of medical bacteriology, later called microbiological and parasitology, over the past 94 years.

The author describes the work of the Standing bacteriological station established in 1922 in Zajecar, led by dr Kosta Todorović, and serves the famous bacteriologist, professor of Kiev. dr Vsevolod Ljubinski, which had great significance both for the development of medical bacteriology in the area of the Timok region and for the development of other branches of preventive medicine, particulary epidemiology and hygiene.

The largest contribution to medical bacteriology, between the two world wars in the House Public Health in Zajecar, and later, after World War II, in Hygiene, now at the Institute for Public Health Timok"in Zajecar, was the discovery of infectious and parasitic diseases, particularly syphilis and malaria, and intestinal infectious diseases.

In his article, the author describes the working conditions, equipment, contents and methods of bacteriological, or micorobiological diagnostics and lists the doctors who took part in it. In addition to the contribution of bacteriological, ie microbiologically, serological and parasitologicaldiagnostics, is a significant contribution to the development of serological and virological diagnosis in certain diseases and the use of susceptibility testing for the treatment of infectious diseases.

\footnotetext{
1 Др Петар Пауновић, учитељ здравља, Зајечар.

2 Др Слађана Ђорђевић, спец. микробиологије са паразитологијом, Зајечар.
} 
Бактериологија Завода у Зајечару допринела је развоју микробиолошке дијагностике оснивањем микробиолошких службии отварањем микробиолошких лабораторија у Бору, Неготину, Кладову и Кюажевиу, затим едукацијом лекара и лабораторијских техничара и указивањем помоћи $у$ организачији лабораторијског рада и обради узорака различитог материјала узетих и подвргнутих микробиолошко-серолошким анализама.

Рад има историјско-медицински значај и представља скроман допринос историји превентивно-медицинских струка Тимочке крајине.

Кључне речи: медицинске струке, медииинска бактериологија, Тимочка крајина, Завод за јавно здравље „Тимок“ у Зајечару.
Bacteriology of the Institute in Zajecar contributed to the development of microbiological diagnostics and establishment of micorbiologocal services and opening of microbiological laboratory at Bor, Negotin, Kladovo and Knjazevac, training of doctors and laboratory technicians, and be helped in the organization of laboratory work and processing of samples of different materials taken and subjected to microbiological-serological analysis.

The work has a historical and medical importance and represents a modest contribution to the history of preventive medical professions in Timok region.

Keywords: medical profession, medical bacteriology, Timok region, The Institute of Public Health "Timok” in Zajecar.

\section{УВОД}

И страживања у области развоја превентивне медицине Тимочке крајине током више деценија уназад омогућила су да се напише и историја медицинских струка превентивне медицине имајући у првом реду медицинску бактериологију, епидемиологију, хигијену и социјалну медицину.(1) У првом делу овог рада описан је развој медицинских струка превентивне медицине у Заводу за јавно здравље „Тимок“ у Зајечару, а у другом историјат медицинских струка превентивне медицине на целом подручју Тимочке крајине.

У последњих неколико деценија јављају се мишљења да све оно што се ради у медицини има превентивни карактер, па тако свака од грана медицине може представљати и превентивну медицину. Када је реч о превентивној медицини у ужем смислу речи, треба имати у виду да се у оквиру медицинских активности налазе оне које полазе од односа медицине са на- родом, које се односе на рад у заједници, посебно са здравим људима, на активности у свакодневном животу, како у мирним тако и и ванредним ситуацијама. Речник, метод и садржај рада превентивно-медицинских активности је другачији од осталих медицинских струка. Треба узети у обзир и друштвене околности и здравствену културу у којима су настале па чак идеологију и филозофију које су утицале на њихов развој.

Историја медицинских струка превентивне медицине Тимочке крајине, односи се на период од 1837. до 2013. године. У овом раду биће описан историјски развој медицинске бактериологије у Заводу за јавно здравље „Тимок“ у Зајечару, а касније и историјски развој осталих медицинских струка:епидемиологије, хигијене, социјалне медицине и здравственог васпитања. 


\section{МЕДИЦИНСКА БАКТЕРИОЛОГИЈА}

I

Бактериологија је наука о бактеријама и њиховом животу. Она открива етиологију, начин инфекције и патогенизам, поставља лабораторијску дијагнозу и изналази сврсисходан начин лечења заразних болести антибиотицима. Први је почео да се бави истраживањем у области бактериологије Antony von Loevenhoch (1632-1723) који је посматрао под микроскопом протозое. Године 1678. открио је бактерије у наслагама својих зуба, а потом и у људском и животињском измету.

Медицинска бактериологија као медицинска научна грана развија се под вођством Luisa Pastera око седамдесетих година XIX века у Паризу. Захваљујући Пастеру зачета су многа знања о бактеријама, њиховом патогеном дејству, о имунитетном одговору зараженог организма и могућностима цепљења ради заштите од инфекција, затим о стерилизацији и уништавању бактерија...

Пастер је у почетку користио општи назив бактериологија, али је касније назив микробиологије био сврсисходнији јер се у микробе убрајају вируси, рикеције, фунги и паразити. Luis Paster и Robert Koch су пионири модерне микробиологије. ${ }^{(2)}$

\section{II}

На нашем простору интересовања болница за набавку микроскопа ради дијагностиковања заразе луесом и маларијом такође се рађају крајем XIX века. Прва интересовања за дијагностиковање луеса и маларије су почетак развоја бактериологије на подручју Тимочке крајине, а када је реч о маларији - и паразитологије. Без микроскопа то није било могуће. Потребу за микроскопом показале су болнице у Књажевцу и Зајечару. Први микроскоп је имала неготинска болница. У инвентару неготинске болнице 1899. године пописан је и микроскоп у одељку „лекарске ствари“.(1) То само по себи значи да је постојао и неки простор и опрема, макар само и један сто на којем је он стајао, што би могло представљати и прву бактериолошку лабораторију на подручју Тимочке крајине. Школски лекар др Душан Поповић и др Лаза Илић удружују средства и 1900. године купују микроскоп за природњачки кабинет зајечарске гимназије (Извештај зајечарске гимназије). ${ }^{(3)}$

Не постоје прецизни подаци када су остале болнице набавиле микроскопе, јер у пописима болничких ствари зајечарске, бољевачке и књажевачке болнице почетком $\mathrm{XX}$ века нема још увек микроскопа. Велики значај за развој бактериологије у Србији, а посебно на подручју Тимочке крајине, имало је оснивање Пастеровог завода у Нишу 1900. године. Он је био формиран како би се обавило цепљење серумом, а касније и вакцином, особа уједених од бесних животиња, али током времена у њему се развијала и бактериологија.

Почетком I светског рата, приликом одступања наше војске ка Приштини, опрема Пастеровог завода је заробљена у Крушевцу и однесена у Бугарску. ${ }^{(4)}$ За време I светског рата Пастеров завод у Нишу није постојао. То је успорило развој бактериолошке дијагностике на подручју југоисточне Србије.

\section{III}

После I светског рата пришло се обнављању санитетских установа у Србији. За 1920/21. годину предвиђена су средства из буџета за сталну епидемијску станицу у Прахову и сталне венеричне амбуланте у Доњем Милановцу, Књажевцу и Неготину, а 1922. године предвиђа се отварање још три бактериолошке станице у Србији. Те године при војној болници у Зајечару отвара се Стална бактериолошка станица чији је шеф др Коста Тодоровић. У њој ради и проф. др Всеволд Љубински из Кијева, који остаје у Зајечару до 1929. године. То се може сматрати почетком бактериолошке дијагностике у Тимочкој крајини, а проф. др Всеволд Љубински, први бактериолог Тимочке крајине. ${ }^{(5)}$ 


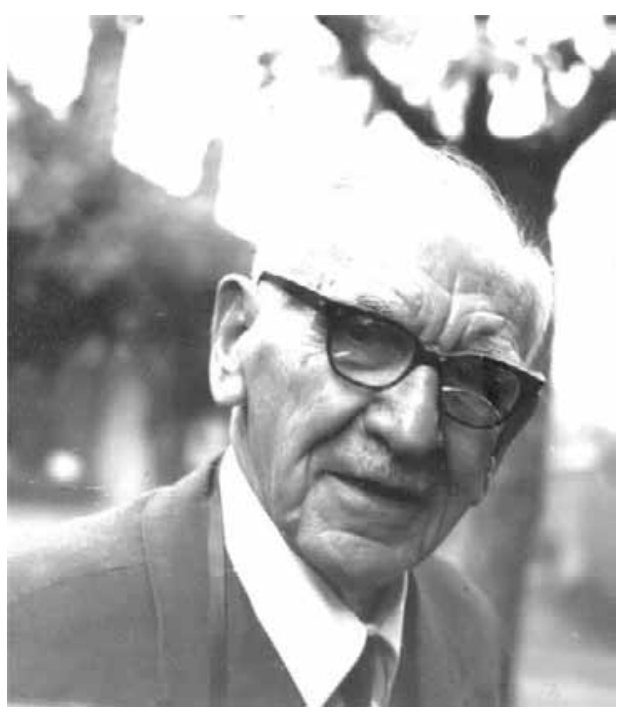

Др Коста Тодоровић

Стална бактериолошка станица у Зајечару, настала 1922. године, претеча је данашњој бактериологији у Заводу за јавно здравље „Тимок“ у Зајечару. Њено оснивање може се сматрати почетком бактериолошке дијагностике у Тимочкој крајини који се одиграо пре 94 године. Она је претеча бактериологији и у другим здравственим установама на подручју Тимочке крајине. Данас су то микробиолошке лабораторије у Књажевцу, Бору, Неготину и Кладову које су настале уз едукацију лекара и лабораната и стручно-методолошку помоћ Завода за јавно здравље „Тимок“ у Зајечару.

После оснивања Дома народног здравља у Зајечару 1930. године, микробиологијом и паразитологијом у Дому бави се др Младен

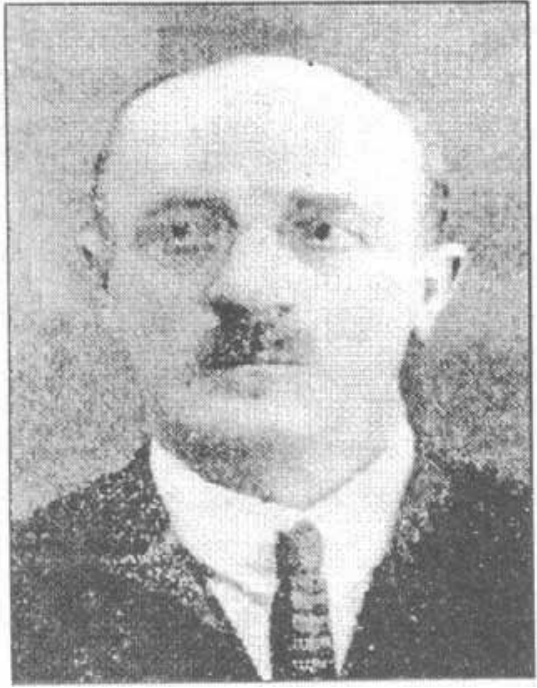

Др Всеволд Љубински

Хаџи-Павловић, који није био микробиолог. У то време у Дому народног здравља постоји „лабораторијска дијагностика, микробиолошко-серолошка и хемијска“". Тада се у области микробиологије рађа и серологија. Један део материјала са подручја Тимочке крајинеслатје бактериолошкој лабораторији Епидемиолошког завода у Нишу.

У извештају о раду Дома народног здравља за 1931. и 1932. годину могуће је имати увид и у рад лабораторије, што само по себи говори од какве су важности те активности биле. У следећем прегледу може се видети да се рад лабораторије односи на бактериолошки преглед разних узорака различитог материјала.

Табела 1. Преглед лабораторијског рада у Дому народног здравља у Зајечару.

\begin{tabular}{llll}
\hline Врста и број прегледа & 1931. & \multicolumn{2}{l}{ 1932. година } \\
\hline Серолошке, бакт. и хем. анализе & 7779 & 7005 & мање 9\% \\
Серолошке анализе на сифилис & 6226 & 5012 & мање $10 \%$ \\
Бактериолошке анализе & 1199 & 1322 & мање 9\% \\
Хемијске анализе & 357 & 742 & више $51 \%$ \\
\hline
\end{tabular}


На основу овог прегледа види се да су активности на сузбијању сифилиса заузимале значајан простор, а повећање хемиј- ских анализа се односи на контроле узорака хране, што се може видети из прегледа који следи.

Табела 2. Структура материјала прегледаних у лабораторији Дома народног здравља.

\begin{tabular}{lll}
\hline Бактериолошки рад: & 1931. & 1932. година \\
\hline 1. испљувака & 141 & 116 \\
2. секрет грла и носа & 584 & 427 \\
3 секрет гениталних органа & 90 & 101 \\
4. преглед крви & 148 & 369 \\
5. преглед урина & 6 & 20 \\
6. преглед фецеса & 86 & 115 \\
7. преглед ликвора & 32 & 38 \\
8. преглед гноја & 68 & 54 \\
9. преглед ексудата & 9 & 24 \\
10. преглед вода (бактериолошки) & 31 & 48 \\
11. остало & 4 & 10 \\
Хемијски рад: & 1931. & 1932. година \\
\hline 1. преглед урина & 339 & 589 \\
2. преглед желудачних сокова & 6 & 7 \\
3.преглед ликвора & 8 & 27 \\
4. преглед животних намирница & 1 & 105 \\
5. остало & 3 & 8 \\
\hline
\end{tabular}

Из овог прегледа лабораторијских услуга видиседаје број узорака мањиу 1932. години у односу на 1931. за 9\%, а број серолошких анализа на сифилис чак за $19 \%$. Смањење ових анализа објашњава се тиме што је амбуланта за кожно-венеричне болести у Бољевцу мање радила „услед одсуствовања и болести особља, а и Дом народног здравља у Зајечару је у 1932. години, остао само на једном лекару“. Због тога није настављено узимање крви на луес код ђака у склопу систематског истраживања луеса започетог
1931. године. Бактериолошке активности су у 1932. години повећане за $9 \%$ због честе појаве трбушног тифуса и срдобоље у тој години. Због тога је повећан број прегледа крви и фесеца у 1932. години у односу на 1931. Хемијске активности у лабораторији су повећане за 52\%, због повећања броја узорака свих врста материјала, а посебно урина и животних намирница.

Када је реч о лабораторијском раду код појединих важнијих и чешћих обољења, он је видљив из прегледа у даљем тексту:

Табела 3. Преглед бактериолошког рада код важнијих и чешћих обољења.

\begin{tabular}{llll}
\hline Обољење & позитиван & негативан & број \\
& налаз & налаз & болесника \\
\hline 1. хемокултура групе тифа & 108 & 173 & 164 \\
2. аглутин. код групе тифа (Видал) & 152 & 130 & 164 \\
3. копрокултура на бац. дизентер. & 22 & 78 & 22 \\
4. спутум на бац. туберкулозе & 26 & 94 & 25 \\
5. секрет из полних органа на Го & 30 & 77 & 27 \\
6. секрет улк. дур. на бледе спир. & 5 & 7 & 5 \\
7. секрет из улц. меки шанкр & 3 & 5 & 3 \\
8. гној из пустуле на антракс & 3 & 2 & 2 \\
9. крв на паразите маларије & 4 & 14 & 4 \\
10. секр. из грла на бац. дифтерије & 75 & 352 & 52 \\
\hline
\end{tabular}


Из поменутог прегледа види се да су од 207 пријављених случајева трбушног тифуса - 164 потврђена у лабораторији, а од 315 пријављених случајева дизентерије само код 22 дијагноза је потврђена и лабораторијски; код дифтерије од 142 случаја лабораторијским налазом је потврђено 50.

Велики обим активности у лабораторији заузимала је серодијагноза сифилиса. 5.012 узорака крви и 29 узорака ликвора узетих од 4.325, односно 29 прегледаних лица били су позитивни на на луес у 1.757 случајева, односно када је реч о ликвору у 27 случајева. Око 40\% испитаних узорака било је негативно, а код $3 \%$ резултат је био нејасан. Када је реч о луесу, који је био велики јавноздравствени проблем на подручју Дома народног здравља у Зајечару, позитивним су сматрани сви они резултати који су макар само у једној реакцији били позитивни.

\section{IV}

Почетком тридесетих година XX века у бактериолошком одељењу Дома народног здравља у Зајечару радила је повремено др Десанка Ивановић (касније Ђермановић), микробиолог. После 1933. она ради исти посао у школској поликлиници. Не умањујући значај рада других микробиолога у Тимочкој крајини, који су били пионири у том послу, др Десанка Ђермановић се може сматрати утемељитељком бактериологије на подручју Тимочке крајине.

Број бактериолошко-серолошких анализа се повећавао из годинеу годину. У то време рађене су бројне анализе (бактериолошкосеролошки прегледи) у лабораторији Дома. Укупно је у 1935. години извршено 14.208 анализа од којих серолошких било 12.580 а бактериолошких 1.628. Колики је обим тих послова био види се из података да је у лабораторији Хигијенског завода у Нишу исте године урађено 15.788 анализа, од тога 11.248 серолошких и 4.546 бактериолошких прегледа. У лабораторији Дома народног здравља у Зајечару у односу на лабораторију у Нишу урађено је 111,90\% серолошких прегледа. Веома је богат и разноврстан низ анализа које су урађене у лабораторији Дома, а то су: прегледи брисева на дифтерију, прегледи копрокултура на групу тифа, хемокултура, Видалових серолошких реакција, прегледа на антракс, ликвора на бактериолошки преглед, тражење у спутуму Коховог бацила, преглед уретралног секрета на гонококе и урина припремљеног за биолошки оглед на Трепонему палидум, тражена је бледа спирохета и Дикреов бацил, прегледи крви на маларију (терцијана је налажена шест пута више, него остало), прављене су аутовакцине, рађене су серолошке реакције по Вајнбергу и већи број анализа на луес.

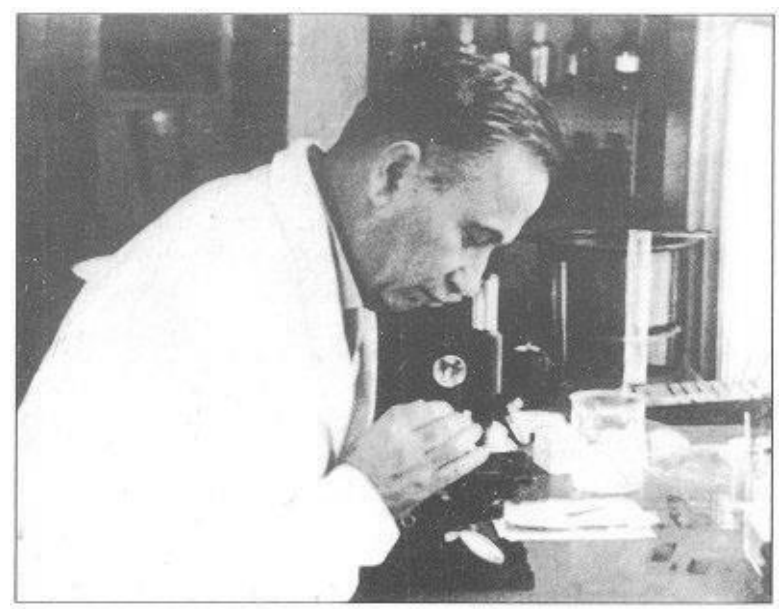

Др Мићо Мићовић, бактериолог

Позних тридесетих година XX века за в.д. директора Дома здравља у Зајечару долази др Марко Ђермановић. Др Десанка Ђермановић, сада супруга в.д. директора, ради као бактериолог до 11. новембра 1943. године, остајући на том послу за време рата и после ослобођења. У једном периоду током II светског рата она је била једини лекар у Дому народног здравља у Зајечару, обављајући, према потреби, и друге послове из области превентивне медицине. За стручност, приљежност у раду, одговорност, однос према колегама и пацијентима др Десанка Ђермановић је добила Орден рада са сребрном звездом, а 1968. године награду „Ослобођење града Зајечара“". 
Др Мићо Мићовић, бактериолог, дошао је у Дом здравља у Зајечару 1943. и започео свој рад на бактериолошкој дијагностици. Пред крај рата он је био мобилисан и отеран на фронт, тако да је бактериолошка дијагностика остала на др Десанки Ђермановић. V

После II светског рата долази до реорганизације здравствене службе на подручју Тимочке крајине и до припајања Санитарноепидемиолошке станице у Неготину Санитарно-епидемиолошкој станици у Зајечару. У Санитарно-епидемиолошкој станици у Неготину у то време ради др Светислав Атанацковић, први школовани малариолог у Тимочкој крајини, који је завршио студије у Паризу. У то време др Мићо Мићовић и др Светислав Атанацковић, потоњи директори хигијенских завода у Зајечару и Неготину, удружују рад на унапређивању микробиолошке и паразитолошке дијагностике на подручју Тимочке крајине.

Бактериологија је дала велики допринос истраживањима ендемског сифилиса у Тимочкој крајини. Први систематски прегледи започети су средином тридесетих година XX века, а затим настављени средином рата. После рата веома интензивно се трага за оболелима од ендемског луеса коришћењем серолошких дијагностичких метода. Више десетина хиљада узорака крви је узето и анализирано у микробилошкој лабораторији Завода за здравствену заштиту у Зајечару. Најзад, осамдесетих година XX века ендемски сифилис је савладан. Проглашено је да је искорењен.

На дан 1. јануара 1950. године у Санитарно-епидемиолошкој станици у Зајечару радили су као бактериолози др Мићо Мићовић, бактериолог, др Десанка Ђермановић, бактериолог, и др Светислав Атанацковић, малариолог. У то време у Санитарно-епидемиолошкој станици у Зајечару обављани су: бактериолошки прегледи (хемокултуре, копрокултуре, уринокултуре), серолошке реакције (Widal-ова, Weil-
Felix-ова реакција преципитације ) и бактериолошки прегледи воде и животних намирница.

Санитарно-епидемиолошка станица располагалаје следећом опремом и ,потребним уређајима за серолошка и бактериолошка испитивања“: аутоклав електрични, суви стерилизатор електрични, термостат електрични, електрично водено купатило, апарат за Лефлеров серум, мућкалица електрична, електрична и ручна центрифуга, електрична центрифуга за млеко, микроскопи (2 ком.), и један у Неготину, фрижидери (2 ком., од којих је један био неисправан), Кохов лонац (неисправан), полариметар за шећер, урометар по Коварском, аглутиноскоп, ваге обичне (2 ком.), хемоцитометри, хемометри, цевчице за седиментацију, пипете (довољан број), епрувете и Петријеве шоље, реагенције и остало за рад.

Тако је писало у једном документу у коме је сачуван списак опреме. Недостајале су посуде за слање заразног материјала, епрувете за слање крви и заморчад за серолошка испитивања.

\section{VI}

На постизање бољих резултата у раду негативно су се одражавали услови смештаја. Санитарно-епидемиолошка станица у Зајечару била је у малој приватној згради за становање, без споредних просторија. Постојао је план за зидање нове зграде у 1948. години. Тада је ископан и темељ, али је Плански сектор Министарства за здравље три пута мењао план, па се у 1949. години одустало од изградње. У међувремену изграђена је нова, наменска зграда за завод у Сремској улици, број 13.

Године 1953. Санитарно-епидемиолошка станица у Зајечару постала је Хигијенски завод. Када се новембра месеца 1964. године Хигијенски завод преселио у нову зграду у Сремској 13, створени су услови за даљи развој микробиологије, серологије и паразитологије. Једно време, поред др Миће Мићовића и др Десанке Ђермановић, 
бактериолошком дијагностиком бавио се и др Михајло Тошић, а 1964. године на специјализацију микробиологије примљена је др Бранислава Крстић. Нешто касније на специјализацију из микробиологије примљена је др Верица Пауновић из Бора. У том периоду у Завод долази и бактериолог др Зоран Каваин. Тада су постојале лабораторијске огледне животиње које су коришћене за микробиолошку дијагностику. ${ }^{(6)}$

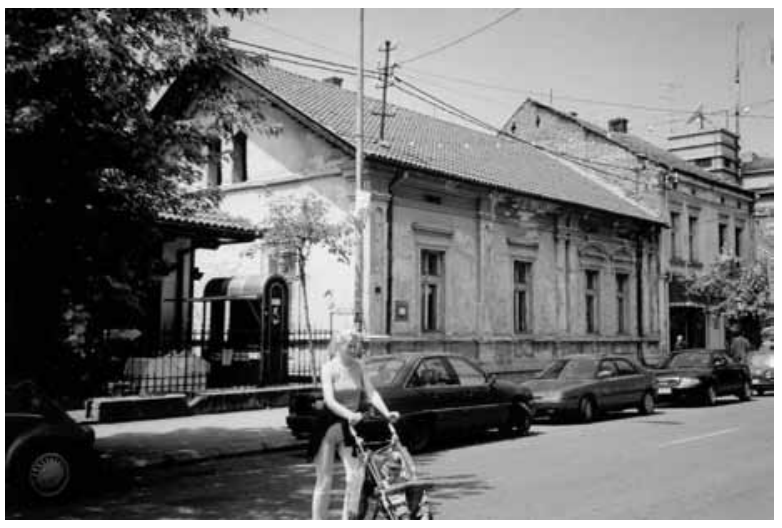

Зграда у улици Љубе Нешића у којој је била микробиолошка лабораторија после II светског рата

Пред крај шездесетих година на специјализацију микробиологије примљена је др Драга Јолић из Неготина. Тада је Завод имао веома јаку микробиолошку дијагностику. Захваљујући сарадњи са микробиолозима са BMA, микробиолошка дијагностика у Заводу постала је чувена у целој Србији.

Након дезинтеграције здравствених установа на подручју Тимочке крајине 1970. године, из Завода одлазе микробиолози др Зоран Кавајин, др Верица Пауновић из Бора и др Драга Јолић из Неготина, а специјализацију микробилогије започињу др Војислава Смичковић из Зајечара и др Станоје Живуловић из Неготина 1973. године. Нешто касније долази и др Дренка Пауновић. Доласком др Војиславе Смичковић започиње рад из домена санитарне микробиологије.

Иако су формиране микробиолошке лабораторије у Неготину и Бору почеле да раде са доласком специјалиста из Завода, микробиолошка лабораторија у Заводу у Зајечару и даље је била централна микро- биолошка лабораторија за цело подручје Тимочке крајине. Какво је стање било у микробиолошкој лабораторији у Зајечару,најбоље се може видети из извештаја Републичке комисије за надзор над стручним радом извршеним у децембру 1987. године.

Микробиолошка дијагностика обављана је у оквиру Одељења за епидемиологију са микробиологијом и ДДД службе и њоме је руководила лекар специјалиста микробиолог прим. др Бранислава Крстић са двадесетак година специјалистичког стажа. У то време имала је одељење са 3 лекара и 16 лабораторијских техничара, од којих је троје имало вишу школу. Како је било неопходно да микробиолошка лабораторија ради преко целог дана, рад је организован у три смене и одвијао се у трајању од 7 до 20 часова. Дешавало се, истина ређе, да се и у току ноћи неко појави ради неке хитне ствари. У том случају су се пацијенти најчешће јављали Душану Михајловићу, лабораторијском техничару, који је становао у непосредној близини Завода, и који је увек и без резерве излазио у сусрет свакоме без разлике. Тако су благодарећи доброј организацији и великом пожртвовању и ентузијазму Душана Михајловића врата лабораторије била увек отворена за сваког коме је она била потребна.

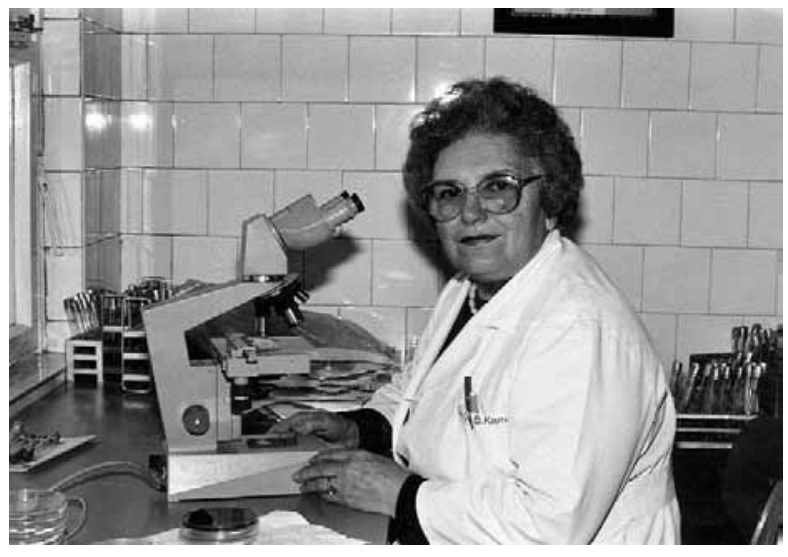

Др Бранислава Крстић, микробиолог

Лабораторијска дијагностика се обавља у партеру и на првом спрату Завода. У партеру је било смештено пријемно одељење. Доста велики простор био је подељен 
на пријемну амбуланту и део у којем се узимао вагинални и уретрални секрет. У том простору обављани су и нужни административни послови. У „Извештају о надзору над стручним радом Завода за заштиту здравља 'Тимок' у Зајечару“(4), који су 18. и 27. децембра 1987. године обавиле проф. др сци. Зденка Јефтић, проф. др сци. Љубица Дрезгић и проф. др сци. Вукица Михајловић, записано је следеће: „Оно што импресионира је чињеница да сав посао око пријема материјала обавља само један техничар, а служба одлично функционише (нема дугог чекања пацијената). У току целог радног времена лаборанти из лабораторије долазе по узети материјал који се континуирано у лабораторији даље обрађује.“

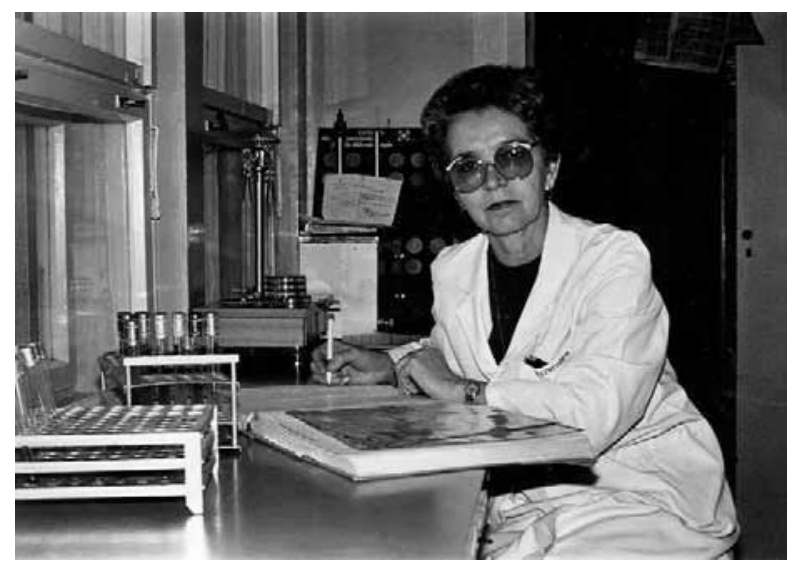

Др Војислава Смичковић, микробиолог

У непосредној близини пријемне амбуланте налазила се посебно опремљена амбуланта за узимање вагиналних и уретралних секрета. Просторија је била опремљена врло добро како за узимање материјала тако и за његову примарну обраду (прављење директних микроскопских препарата). Завод је имао своје овнове чија крв се користила за рад у лабораторији.

Други део лабораторије био је смештен на првом спрату у једном делу зграде, у четири лабораторијске просторије: лабораторија са санитарном микробиологијом, серолошка дијагностика, урино и копрокултуре и лабораторија за туберкулозу, клицоноштво и комплетну паразитолошку и микробиолошку дијагностику.

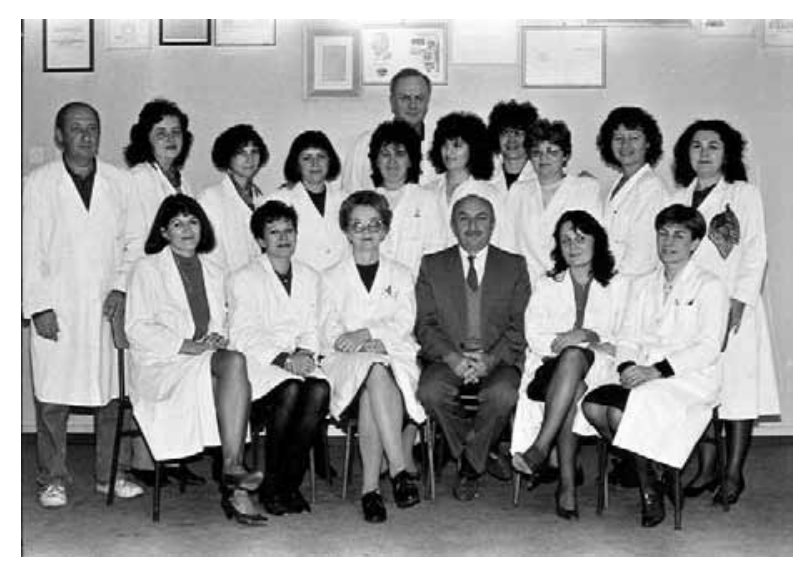

Одељење за микробиологију и паразитологију Завода

Флуоресцентни микроскоп је био смештен у једној малој посебно адаптираној просторији. Поред поменутих постојала је и посебна просторија за спремање хранљивих подлога која је била опремљена бактерицидним лампама и полицама за чување подлога и стерилног посуђа. За стерилизацију су коришћење две просторије тако да је стерилизација чистог од стерилизације прљавог посуђа била одвојена. Просторије су биле снабдевене вентилаторима, тако да су се добро проветравале и ослобађале сувишне паре. Постојале су и две просторије за прање лабораторијског посуђа и његову припрему, лекарска соба и простор за лабораторијске техничаре.

Када је реч о обиму рада, у поменутом извештају се каже следеће: „Микробиолошка служба има велики број извршених анализа. Тако на пример у 1985. години тај број износи 108.716 , ау 1986. години 106.569.(117).“Било је периода у развоју Завода и година када је број извршених анализа прелазио 200.000. Највише је анализа било у вези са прегледом „клиничког“ материјала столица и урина, између 50.000 и 60.000 анализа годишње у 1985. и 1986. години. Дијагностика луеса се вршила методом РВК по Колмеру, Цитохол и ВДРЛ реакцијама (у 1986. години је било 4.184 анализе). У серолошкој лабораторији врше се AST, W.Rose, RF и CRP прегледи (y 1986. години 3.072 анализе). Вршена je и дијагностика Toxoplasmae, Rubellae (Rubenosticom), ехинококозе и серолошка 
дијагностика салмонела по Widal-y. У то време планирано је да се уведе и серолошка дијагностика вирусних обољења за шта је било потребно створити неопходне услове. ${ }^{(5)}$

У извештају постоји и „оцена о раду“: „Све микробиолошке анализе раде се савременим методама. Обрада материјала и методе анализа су на високом нивоу, јер су млади лекари већи део специјалистичког стажа провели у Београду и Нишу, што нормативна регулисаност и могућност школовања лекара специјалиста то допушта. Заинтересованост и лекара и лабораторијских техничара за освајањем нових метода и проширивањем дијагностике је велика.“(7)

У позним осамдесетим годинама микробиолошка лабораторија Завода могла је да изолује широк спектар бактерија: салмонеле, шигеле, најсерије гонореје, најсерије менинигитиса, кампилобактерије, ентеропатогене ешерихије коли, стептококусе пнеумоније, бета-хемолитичне стрептококусе и друге.

У закључку извештаја је поменуто да „микробиолошка служба располаже веома солидним, вредним лабораторијским техничарима и зрелим лекарима специјалистима који показују интерес и амбицију да микробиолошку службу унапреде и приближе врхунским лабораторијама“. То је био соиијални капитал који је у најтежим годинама сиромаштва и рата помогао да се лабораторија развија и у погледу укључивања у рад нових анализа и опреме и запошљавања младих стручњака за XXI век.

Било је и неких проблема, нпр. да се у једној просторији обавља више анализа, па је требало, рецимо, да се микологија са паразитологијом издвоји, и дат је и предлог да се запосли један дактилограф ради бележења резултата. Крајем осамдесетих година хемијска лабораторија, услед умножавања и проширивања активности везаних за заштиту човекове средине, била је у врло тешкој ситуацији. Лабораторијски простор се састојао од шест просторија и био је тесан за рад. Радни столови су били закрчени без довољно простора за постављање опреме, нити је било простора да се посебни аналитички процеси одвоје. Ни апаратура није била одвојена по делатностима и начину рада. Толико је простор био скучен да је онемогућавао правилан распоред опреме за рад. Тескобан простор је имао за последицу да нису биле одвојене једне од других лабораторије за испитивање воде за пиће од оних за анализу биолошког материјала, као ни лабораторије за површинске воде, отпадне воде и анализу аероседимента. Није постојала ни мерна соба, па су апарати били размештени ту и тамо по разним просторијама. Поред тога, трпели су и прање лабораторијског посуђа, сушење и стерилизација, јер се све то обављало у малој просторији.

\section{VII}

Имајући у виду да је микробиолошка дијагностика била од великог значаја за цело подручје Тимочке крајине наставило се са кадровским јачањем и пријемом нових лекара на специјализацију из микробиологије. Полазило се од тога да ако су из специјализанти из Зајечара, дуже ће се задржати на раду. Међутим, више лекара је после завршене специјализације отишло из Завода, јер Завод није могао да им обезбеди основне услове за живот - кров над главом, тј. стан.

Крајем седамдесетих јавља се велика флуктуација кадрова у микробиолошкој лабораторији Завода у Зајечару. Из Зајечара одлазе микробиолози др Катарина Анић и др Дренка Пауновић, а на специјализацију микробиологије долазе др Весна Марушић (1984), др Драгана Јеленковић (1988) и др Гордана Васиљевић Лучић и др Слађана Ђорђевић (1989) - све из Зајечара. Тако је микробиологија у Заводу подмлађена, чиме је створена перспектива да на дуже време Завод има тим који ће да задовољи све потребе становништва за микробиолошкопаразитолошком дијагностиком. 


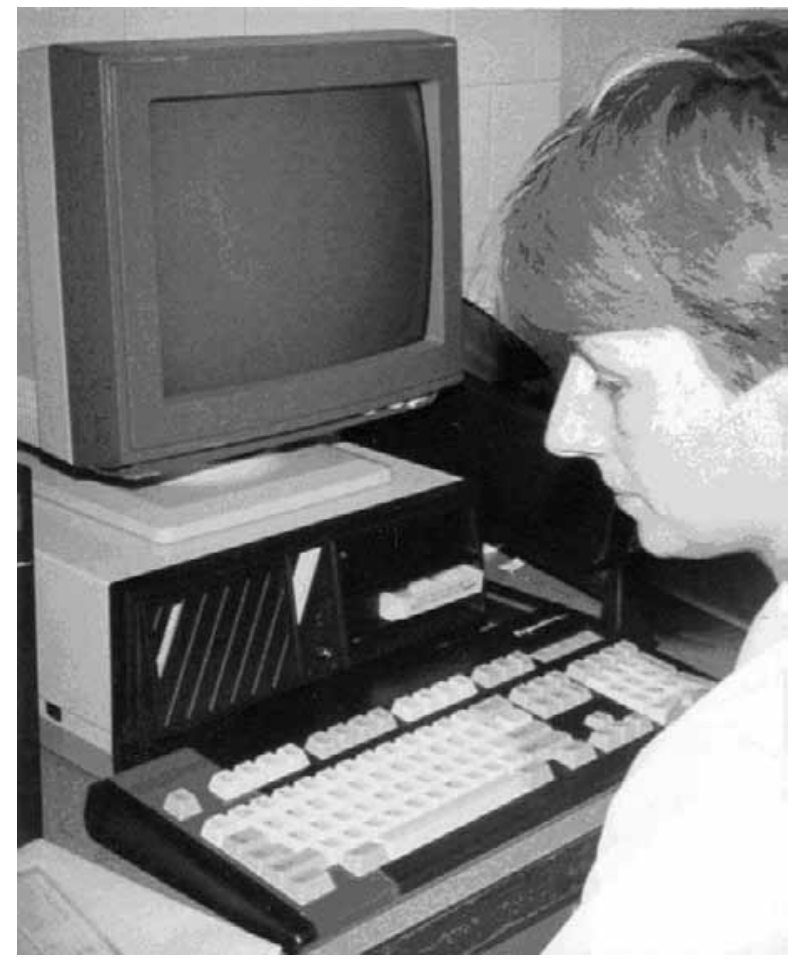

Др Весна Марушић, шефица Одељења за микробилогију

Нови лекари се тражили нове приступе у микробиолошкој дијагностици. Нови приступи нису били могући без савремене опреме, зато је Завод настојао да микробиолошку лабораторију опреми новом опремом. Набављен је апарат за брзу идентификацију бактерија и израду теста осетљивости - АТВ expression sistem. У то време једино је Завод за заштиту здравља „Тимок“ у Зајечару имао такав апарат. Неколико година касније Завод набавља још један савремени апарат - Mini Vidas, за детекцију антигена/антитела из крви пацијента, чиме је проширен избор тестова и унапређена имунодијагностика. У време појаве првих случајева оболелих од сиде на подручју Тимочке крајине Завод је имао и ELISA процесоре. Нови приступи и опрема нашли су се у претесном лабораторијском простору.

Сви специјализанти су на крају специјалистичких студија добијали дипломе и титулу специјалисте микробиологије са паразитологијом.

У то време активности у раду микробилошке лабораторије одвијале су се у доменима рутине и оних делатности које су регулисане посебним правилницима и у оквиру норми за здравство. Нове активности у периоду професионализма захтевале су другачији рад и прилагођавање лекара и техничара, кроз едукацију за нове задатке, и куповину нове опреме. Прилике за развој истраживачких активности изван рутине постојале су у истраживањима осетљивости бактеријске флоре на антибиотике, истраживањима хигијенских прилика у болницама и другим установама, истраживањима квалитета воде за пиће у акумулацијама и истраживањима која су била у вези са интересовањем за рапрострањеност антропозооноза на подручју Тимочке крајине. Том приликом је, крајем $\mathrm{XX}$ века, направљен и виваријум и тако је Завод после 30 година поново добио лабораторијске животиње за истраживања мишје грознице. То су биле могућности које су само делимично искоришћење, а могле су послужити да из тих истраживачких пројеката лабораторијски стручњаци израсту у магистре и докторе наука.

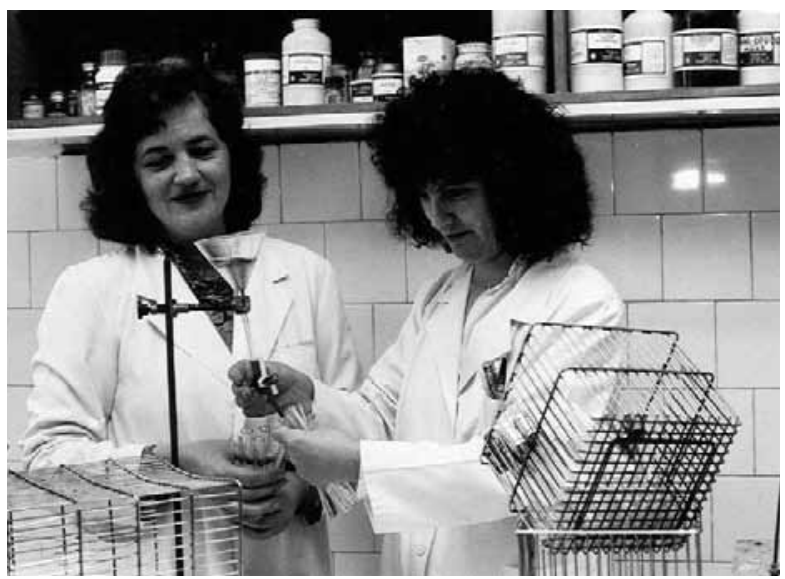

Лаборанткиње у микробилошкој лабораторији Завода

У кооперацији са Ветеринарским центром у Зајечару стручњаци Завода раде на истраживањима проширености ехинококозе на подручју Тимочке крајине. Др Душан Стојановић, епидемиолог и др Слађана Ђорђевић, микробиолог, на међународном стручном састанку у Лисабону, 1996. године, реферишу о резултатима рада на поменутом пројекту који се бавио раширеношћу ехинококозе на подручју Тимочке крајине. ${ }^{(8)}$ 


\section{VIII}

До краја XX века развој микробиологије у Заводу стигао је дотле да је на микробиолошкој дијагностици радило пет микробиолога и један микробиолог на специјализацији - др Татјана Јанковић. Да би се изашло новим потребама у сусрет, затворена је тераса на трећем спрату Завода и тако је проширен простор за смештај микробиолошке лабораторије.

Усељење у тај простор започело је 2007. године. Микробиолошка дијагностика се спроводи у оквиру Службе за епидемиологију и микробиологију која као таква постоји до 2006. године. Од 2007. године микробиолошка дијагностика се одвија у Центру за микробиологију, као самосталном центру, у коме се обрађују само хумани узорци. Санитарна микробиологија налази своје место у Центру за хигијену и хуману екологију.

Центар за микробиологију је реновиран и у свом простору садржи лабораторију за дијагностику цревних заразних болести, лабораторију за дијагностику генитоуринарних инфекција, лабораторију за туберкулозу, лабораторију за пиокултуре и лабораторију за серолошку дијагностику. У оквиру Центра за микробиологију је и пријемно одељење за узорковање, а посебан простор је опремљен за узорковање гениталних узорака.

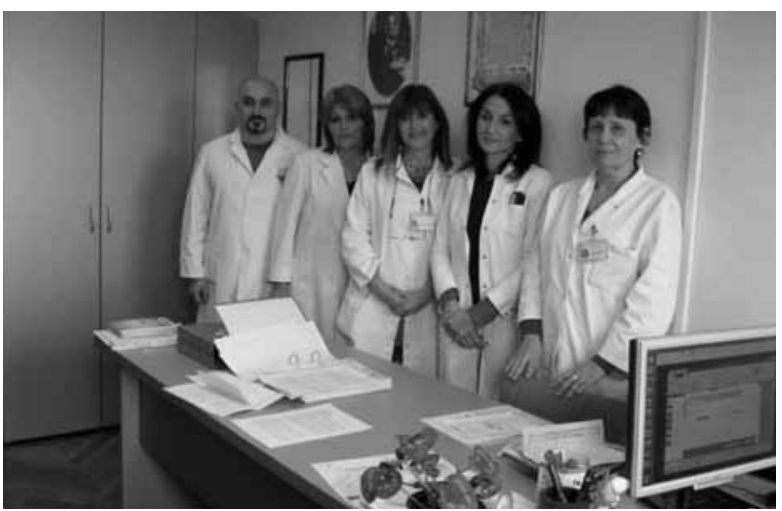

Др Слађана Ђорђевић (у средини), шеф миктобиолошке лабораторије са сарадницима
Деведесетих година, лекари-микробиолози дали су свој допринос пројекту истраживања антропозооноза сарађујући са Медицинским факултетом и Ветеринарским факултетом у Београду.

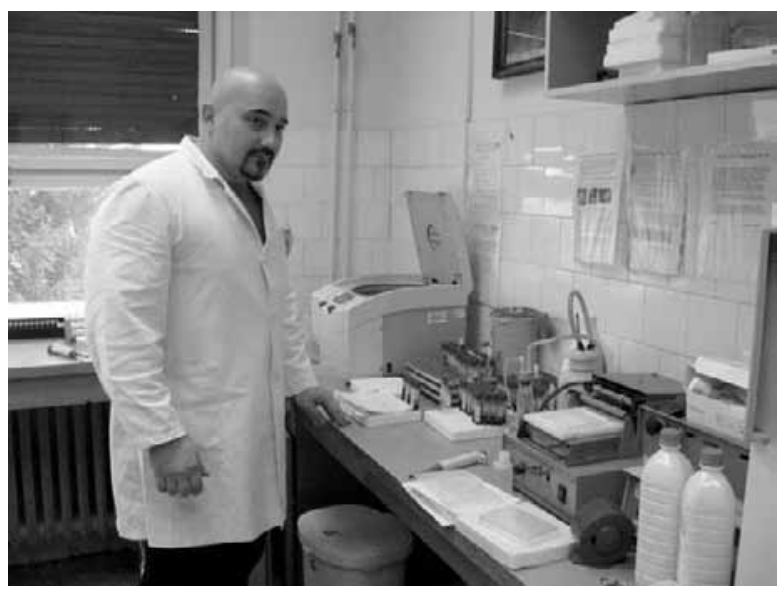

Иван Марковић, виши лабораторијски техничар Завода

Од 2004. године почиње велики пројекат „Контрола туберкулозе у Србији“ у организацији Министарства здравља и Глобал фонда за борбу против сиде, маларије и туберкулозе. Прва фаза пројекта везана је за период 2004-2010. Микробиолози (др Гордана Василијевић Лучић, др Слађана Ђорђевић) и техничари Завода (Станија Гојић, Иван Марковић, Јелена Стевановић, Оливера Миливојевић, Бојана Давидовић) учествују на свим обукама и радионицама. Након сваке пројектне године на годишњим конференцијама презентују се резултати програма. У оквиру пројекта планиране су и изведене супервизорске посете и контроле квалитета. Запослени у Центру за микробиологију редовно присуствују свим семинарима, конференцијама и регионалним састанцима на којима презентују резултате рада микробиолошке лабораторије. Резултати рада оцењивани су одличним оценама. Из средстава пројекта добијен је микроскоп, ламинарна комора, центрифуга и рачунар са штампачем. Пројекат је настављен, а следећи пројектни период трајаће наредних пет година. 
Од 2005. године 33Ј3 „Тимок“ учествује у тридесетомесечном пројекту „Унапређење лабораторијских услуга у Србији“ који спроводи EPTISA у сарадњи са Министарством здравља Србије. Пројекат има за циљ побољшање лабораторијских услуга, стандардизацију метода, осигурање квалитетауслуга. У оквирупројектаодржан јевелики број едукативних стручних семинара и радионица. Из средстава пројекта обезбеђена je опрема - инкубатори, микроскопи, Elisa процесор, аутоклав, ламинарна комора и бројни стручни документи. Лекари Центра (др Татјана Јанковић, др Слађана Ђорђевић) су присуствовале свим едукативним скуповима, а др Слађана Ђорђевић је била и чланица радне групе за израду микробиолошког приручника. Након спроведених обука у оквиру пројекта, у Центар за микробиологију успешно је имплементиран CLSI стандард (Clinical and Laboratory Standards Institute). Менаџмент Завода одлучује да обнови започету стандардизацију система квалитета и кренуло се у активности. Уз велику ангажованост запослених систем управљања менаџмента квалитетом ISO 9001 уведен је јула 2005. године. Као члан Секције за микробиологију СЛД, др Слађана Ђорђевић покренула је иницијативу да се састанак Секције одржи у Зајечару. Године 2006. одржан је састанак Секције у Зајечару, на којој је презентиран WHONET програм за праћење резистенције микроорганизама. Предавање је одржао др Синиша Севић из Клиничког центра Нови Сад.

Центар за микробиологију 33Ј3 „Тимок“ учествује у екстерној контроли квалитета у оквиру пројекта „Унапређење лабораторијских услуга у Србији“ у организацији EPTISA-е 2007. године. У првој екстерној контроликвалитетаучествују44лабораторије из јавног и приватног сектора. Проценат успешности нашег рада је $80 \%, 90 \%$ и $100 \%$ по соју. Друга екстерна контрола квалитета у организацији Референтне лабораторије за међулабораторијско испитивање Градског Завода за јавно здравље Београд била је 2013. године. Задатак контроле било је идентификовање пристиглих сојева, избор антибиотика, препорука за терапију. Центар за микробиологију је добио три соја са описима случајева. Овог пута проценат успешности био је 100\%. Одличан резултат друге екстерне контроле имају још две лабораторије од укупно 24 колико их је учествовало у контроли. У 2013. години Центар за микробиологију учествује у програму екстерне процене квалитета серолошке дијагностике токсоплазмозе у организацији Националне референтне лабораторије за токсоплазмозу Института за медицинска истраживања Београд. У Центар су достављене батерије од шест узорака серума са дефинисаном концентрацијом специфичних IgG и IgM антитела на токсоплазмозу. Задатак је било тестирање серума и приказ концентрација антитела у серуму. Проценат успешности за IgG класу антитела био је 100\%. За IgM класу проценат је био нешто нижи, тако да је препорука НРЛ била да се промени врста теста.

Од 2007. године Центар за микробиологију учествује у пројекту Министарства здравља „Праћење резистенције микроорганизама - MRSA, VRE и Streptococcus pneumoniae - пеницилин резистентан“".

Лекари Центра за микробиологију учествују у раду Комисије за интрахоспиталне инфекције на нивоу 33Ј3 „Тимок“, али и у здравственим установама ЗЦ Зајечар, ДЗ Бољевац, Специјална болница Гамзиградска бања.

Од 2005. године 33Ј3 „Тимок“ учествује у пројекту „Управљање медицинским отпадом“. На стручним састанцима и радионицама активно учествују запослени из Центра за микробиологију (Иван Марковић, Станија Гојић, Милан Трандафиловић, Гордана Јовановић). Из средстава пројекта добијен је аутоклав, обезбеђен је и адаптиран простор за одлагање и уништавање медицинског отпада.

Лекари центра учествују на стручним састанцима и презентирају радове. У Центру за микробиологију се обавља и део 
практичне обуке за ученике Медицинске школе, коју спроводе виши лабораторијски техничар Иван Марковић и др Слађана Ђорђевић.

Министарство здравља и Републички фонд здравственог осигурања током 2013. године раде на припреми нове номенклатуре лабораторијских здравствених услуга на примарном, секундарном и терцијарном нивоу здравствене заштите. По новој номенклатури Центар за микробиологију врши анализе које су предвиђене за делатност Завода. Одређене услуге предвиђене су за делатност установа вишег нивоа које спадају у домен специјализованих, референтних лабораторија, а све су обухваћене истим ценовником.

У 2013. години Центар за Микробиологиjу је обавио следеће активности за потребе јавног здравља. Активности се састоје из микробиолошког прегледа узорака од лица која долазе из ендемских жаришта заразних болести и материјала у циљу испитивања узрочника, резервоара и путева ширења заразних болести. Активности се састоје и из откривања и праћења кретања резистенције из клиничких узорака: метицилин резистентног стафилокока (MRSA), Streptococcus pnaumoniae резистентних на пеницилин и ванкомицин резистентног ентерокока у болничкој средини. Поред тога, обављају се и активности Завода према Референтним лабораторијама.

Надзор над стручним радом Центра за микробиологију је обављен 5. октобра 2012. године. Стручни надзорници су стручњаци Института за јавно здравље „Др Милан Јовановић Батут“: др сци. мед. Милена Васић, др сци. мед. Зорица Јовановски, др Јелена Обрадовић и мр сци. мед. Наташа Галић Живанић. Извештај је показао да је опрема у Центру за микробиологију на задовољавајућем нивоу. Добијена је и ламинарна комора за дијагностику туберкулозе, али недостаје још једна за обраду клиничких узорака. Недостају аутоматизовани системи за узорковање крви и идентификацију микроорганизама. Од
Европске агенције за реконструкцију и развој, у оквиру пројекта „Унапређење лабораторијских услуга у Србији“ у периоду 2006/2008. године“, набављени су многи апарати и сви су били у функцији. Опрема ce редовно контролише баждареним медицинским инструментима, правилно се одржава и сервисира. У центру не постоји информациона мрежа, нити локалан приступ интернет вези, што отежава унос резултата лабораторијских испитивања и коришћење савремене научне литературе.

\section{IX}

Надзор над стручним радом Центра за микробиологију са паразитологијом је имао за циљ да утврди какви су грађевински и технички услови у лабораторији, стање обезбеђености опремом и стање и степен искоришћености опреме високе технолошке вредности. Оцена је била - задовољавајуће/ ћи. У предлогу мера стоји да би требало:

- раздвојити у пријемној канцеларији узорке и пацијенте и увести протокол о узорцима,

- побољшати поступак са неадекватним узорцима,

- обезбедити праћење и континуирану евиденцију о свим дијагностикумима који се користе у лабораторији и

- набавити ламинарну комору за обраду узорка нивоа 2.

На крају, планови Центра усмерени су ка унапређењу система квалитета SRPS ISO/ IEC 17025, едукацији кадрова, опремању савременом опремом и сарадњи и стручним надзором над другим микробиолошким лабораторијама на подручју Тимочке крајине.

У Центру за микробиологију 2013. године радило је 17 запослених: три лекара са специјализацијом из микробиологије са паразитологијом, два виша лабораторијска техничара, седам лабораторијских техничара (два на одређено време), један медицински техничар, један санитарни техничар, један административни радник и два помоћна радника. 
Списак радника Центра за микробиологију:

- начелник центра др мед.Слађана Ђорђевић,

- др мед. Гордана Василијевић Лучић и

- др мед.Татјана Јанковић,

- виши лаб. техничар Иван Марковић,

- виши лаб. техничар Бојана Давидовић,

- лаб. техничар Станија Гојић,

- лаб. техничар Оливера Миливојевић,

- лаб. техничар Јелена Стевановић,

- лаб. техничар Милан Трандафиловић,

- лаб. техничар Снежана Петровић,

- лаб. техничар Дејан Златковић,

- лаб. техничар Бојана Николић,

- мед. техничар Татјана Јанковић,

- сан. техничар Јован Милојковић,

- адм. радник Небојша Џудовић,

- пом. радник Снежана Милојковић,

• пом. радник Гордана Јовановић.

\section{X}

Други део микробиолошке дијагностике пребачен је у домен рада Центра за хигијену и хуману екологију. У домену рада поменутог центра постоји Одељење за санитарну микробиологију. У њему раде два лекара микробиолога: др Весна Марушић и др Драгана Дробњаковић Јеленковић.

У раним седамдесетим годинама XX века микробиолошка лабораторија Завода за здравствену заштиту у Зајечару је била подељена тако да је једна соба била одређена за рад санитарне микробиологије. Највећи број анализа, око 3.000 узорака годишње, односио се на утврђивање микробиолошког квалитета воде за пиће из централних, градских и сеоских водовода и са школских и јавних чесама и из бунара са целог подручја Тимочке крајине. Мањи број анализа односио се на узорке хране и животних намирница. У санитарној микробиологији радила је др Војислава Смичковић која је на тим пословима остала до краја стручне каријере у Заводу. Када је Завод почео да контролише квалитет воде у акумулацијама на подручју Тимочке крајине из којих је коришћена вода за градске водоводе, биолошку контролу је радила Надежда Николић, дипломирани биолог.

Да би се обезбедио квалитетан рад, 1980. године формирани су стручни тимови за здравствену исправност воде за пиће, хране иживотних намирница састављениодлекара специјалиста хигијене, санитарног инжењера, специјалисте санитарног хемичара у којима је др Војислава Смичковић радила на микробиолошкој дијагностици воде за пиће, хране и животних намирница. ${ }^{(9)}$

Проширењем просторија 2002. године и увођењем стандарда SRPS ISO/IEC 17025, Центар за хигијену и хуману екологију је акредитован за област испитивања вода, животних намирница, ваздуха и предмета опште употребе. У Одељењу за санитарну микробиологију овог центра обављају се следеће активности:

1. припрема хранљивих подлога које се користе у Одељењу санитарне микробиологије и у Центру за микробиологију, 2. припрема раствора и реагенаса потребних за микробиолошка и биолошка испитивања,

3. микробиолошко испитивање намирница, вода и предмета опште употребе,

4. микробиолошко и биолошко испитивање површинских и отпадних вода,

5. бактериолошко испитивање стања радних површина, ваздуха, руку радника у оквиру испитивања санитарно-хигијенског стања у здравственим установама и установама које се баве производњом и прометом хране,

6. испитивање стерилности материјала,

7. деконтаминација подлога, прибора, посуђа, као и прање посуђа и прибора који су коришћени током микробиолошког испитивања у Одељењу за санитарну микробиологију,

8. припрема и стерилизација посуђа и прибора који се користе у Центру за микробиологију. 
У Одељењу санитарне микробиологије у оквиру Центра за хигијену и хуману екологију у 2013. години радило је осморо запослених: два лекара са специјализацијом из микробиологије са паразитологијом, један виши лабораторијски техничар, пет лабораторијских техничара и један помоћни радник.

Списак радника Одељења за санитарну микробиологију:

- шеф Одељења санитарне микробиологије др мед. Весна Марушић,

- др мед. Драгана Дробњаковић Јеленковић,

- виши лаб. техничар Валентина Ђурђевић,

- лаб. техничар Љиљана Миленовић,

- лаб. техничар Весна Јовановић,

- лаб. техничар Радица Цветковић,

- лаб. техничар Јелена Илић,

- помоћни радник Мила Серијевић.

\section{ЗАКЈУУЧАК}

Циљ овог рада је највећим делом испуњен. Рад има историјско-медицински значај, а може представљати и поуку за будућност о томе да улога и место превентивне медицине у животу народа је непролазна појава, као што је очување и унапређивање здравља и борба спречавања настанка болести вечна и све значајнија у данашње време у нашој земљи. Имајући у виду да се превентивна медицина бави, пре свега, здрављем у заједници и његовим очувањем и унапређивањем, има се утисак да ће превентивна медицина бити потребна у будућности исто онолико, ако не и више, као што је била потребна у прошлости, али овог пута наоружана новим знањима и могућностима.

Иако је медицинска микробиологија по својој природи дијагностичка дисциплина, она је увек била подршка епидемиологији и хигијени и велика подршка овим медицинским струкама превентивне медицине. Највећи њен допринос је увек био у раном, што раније могућем, откривању проузроковача заразних болести. Медицинска микробиологија у Заводу за јавно здравље „Тимок” у Зајечару тај циљ остварује модерном медицинском опремом којом се може убрзати идентификација проузроковача заразних болести.

Најзад, од свог постојања до данас, микробиолошка дијагностика у Заводу за јавно здравље „Тимок“ у Зајечару стално ради на указивању стручно-методолошке помоћи микробиолошким лабораторијама у Бору, Неготину, Кладову и Књажевцу и едукацији лекара и лабораната у њима.

\section{ЛИТЕРАТУРА}

1. Бошко Поповић, Славен Летица, Милан Јакшић. Медицинске струке. II књига, Југословенска медицинска наклада, Загреб, 1981.

2. Исто.

3. Из Летописа Зајечарске гимназије за школску 1900-1901. годину, Зајечар, 1901.

4. Др Петар Пауновић. Цивилне бриге српске владе на Крфу од 1915. до 1918. године.
5. Др Петар Пауновић. Хигијенске установе на подручју Тимочке области између I и II светског рата, Рајац, 2014.

6. Др Петар Пауновић, Књига о Заводу. Монографија, Завод за заштиту здравља „Тимок“, Зајечар, 2006.

7. Завод за заштиту здравља Републике Србије „Др Милан Јовановић Батут“: Извештај о надзору над стручним радом Завода за заштиту здравља „Тимок“ у Зајечару, број 3181 / 19. 12. 1989. године.

8. Др Петар Пауновић: Књига о Заводу. Монографија, Завод за заштиту здравља „Тимок“, Зајечар, 2006.

Контакт: Др Петар Пауновић, учитељ здравља, Зајечар. 